\title{
Bearing Witness: Maoism as Religion
}

\author{
DAVID E. APTER
}

\begin{abstract}
The role of foreign witnesses in describing exceptional historical events can contribute to the way those events unfold. Three examples serve to illustrate this: Edgar Snow, Anna Louise Strong and Agnes Smedley. At the start of the Chinese communist revolution each of these commentators offered personal testimony to and validation of what became a political myth and was elevated to the status of a state political religion with Mao the central figure. This paper discusses the differences between political religion and religion tout court. It suggests that the former is more ephemeral while the latter is more capable of self-replenishment, leading to the ritualization of the first in the exercise of state power. It also deals with the question of socialism as proto-religion and the problems posed by its disappearance.*
\end{abstract}

Keywords: Witnessing, presentism, political religion, testimony, discourse, Maoism.

\section{Introduction}

All great events have commentators whose accounts help shape the way these events will be remembered and understood. This is especially the case when dealing with exceptional historical moments - moments so telling that they constitute ruptures in time, thought and political structure. The Chinese communist revolution was one such moment. Judgements made about it on the spot, and in context, especially those that once appeared definitive, have so often been subject to periodic revision that there is now a history of different interpretations. The revolution has become a subject in itself, as succeeding generations of observers go over the ground and reinterpret its meaning. In many cases such distancing from original events has made for more judicious judgements, as the works of Stuart Schram attest. There is a danger though that subsequent perspectives may omit and alter facts that loomed significant at the time, especially to the actual participants. What has been called 'presentism', imposing the present on the past, becomes a problem if it distorts the perceptual universe of those who were involved at the time. 
Of course, over time it is inevitable that not only will interpretations change, but so too the accuracy of perception and the status of 'facts'. A good example is in the diametrically opposed points of view about Mao represented by Edgar Snow and Jung Chang and Jon Halliday in books 67 years apart. Snow presented Mao autobiographically. In selecting from his notes of the interview made in Bao'an, Snow allowed Mao to link his personal vicissitudes to his political awakening and the shaping of his radical ideas, to his views of history and the progressive nature of the Chinese revolution. In Snow's commentary what emerges is a picture of an exceptional intellectual-revolutionary whose 'Chinese' Marxism was a dialectic with history tempered by a strong sense of practical realism, and a pragmatic view of strategy and tactics. In what became a prophetic comment, Snow concludes the main part of this 'autobiography' by saying that Mao's account

had begun to pass out of the category of 'personal history', and to sublimate itself somehow intangibly in the career of a great movement in which, though he retained a dominant role, you could not see him clearly as a personality. It was no longer the 'I' but the 'we'; no longer Mao Tse-tung, but the Red Army; no longer a subjective impression of the experiences of a single life, but an objective record by a bystander concerned with the mutations of collective human destiny as the material of history. (Snow 1984: 166)

To Chang and Halliday, looking back on virtually the whole period of communist rule in China, this is so much nonsense. In their look at the 'objective record', the real Mao, that is the historical actor, was little more than a tyrant and killer whose main attribute was to be more ruthless than anyone else. The 'personality' of Mao in Mao, the Unknown Story (Chang and Halliday 2005) was simply such a passion for the exercise of total power that he became responsible for 'mutations of collective human destiny' of a kind that resulted in millions of deaths. From such a perspective, to look back on Mao is to recognize that it is death itself that becomes the 'material of history'.

So vast are the discrepancies between the two interpretations, between Snow's and Chang and Halliday's, between the human and the inhuman Mao, that they invite general speculation about the defining power of power itself on personality. One might well ask whether Chang and Halliday's revisionism represents an example of warranted or unwarranted presentism. ${ }^{1}$ Certainly it would wipe out the earlier consideration, that of an original evolving, learning, philosophical, thinker/doer obsessed with continuing revolution as both theory and practice. Instead of a fitting addition to the Marxian pantheon, one finds a blemished 'Mao', 
condemned from the start by an original sin of ruthless ambition, whose madness did not prevent him from shrewdly playing a game of pure power in the name of China's revolution.

There is no definitive way to resolve such divergences. Nor is it the intention here to try to balance such widely differing accounts. But there are reasons why it is useful to reconsider the early revolutionary Mao in the context of his original circumstances, especially from the standpoint of those outsiders who were sufficiently dedicated to Mao and his role that they contributed to what, from Chang and Halliday's perspective, was the myth of Mao-a myth that their book tries to puncture. Yet it is precisely this mythic factor that helps account for the very power Mao exercised, especially in bringing about the structural alterations in character of the revolution itself, as the party evolved, first in the emergence of Mao's own fraction (by no means the major one) into a virtual cult, and from there the elevation of Mao's version of Chinese Marxism into nothing less than a secular state religion.

In these terms it is useful to examine the special role in making and interpreting history of those select few among the outsiders whose writings became particularly influential in their time and who, by themselves serving as witnesses, became part of the situation as well as commentators on it. One might say that they became, to use Durkheim's terms, social facts. For not only did they describe the events that they saw in definitive ways but they also included themselves in what they described. ${ }^{2}$

In good measure those selected here for discussion were those who apparently came to believe in the rightness of the Chinese revolution as Mao's revolution. Convinced by the dramatic events they saw unfolding under their reportorial noses, they considered the Chinese communist revolution not simply as a remarkable phenomenon, but in some yet undisclosed form a possible political future solution, and more hopefully even some sort of democracy, especially since the readily available alternatives appeared unappetizing, namely fascism in Italy, Germany and Japan (not to speak of the 'proto-fascism' within the Guomindang (GMD)). Nor were they happy about the way capitalism played itself out, prone to both imperialism and internal crises, especially during the period which, if it was revolutionary in China, was marked by the Great Depression in the United States.

In this context the role of Mao and the evolution of the Chinese Communist Party (CCP) under Mao seemed more than a remarkable phenomenon. It became for the witnesses a way of understanding the power of Maoism in more universal terms, i.e. as a belief system. This 
accounts for the more general concern in this discussion, a consideration of Maoism as a proto-religious phenomenon. I want to examine this aspect of Maoism for two reasons. Firstly, it tends to be forgotten in the context of the China of today. This is unfortunate since, despite China's astonishing economic performance, it would lead us to ignore a certain remaining moral nostalgia for Maoism (which invites speculation about the possibility that in some refurbished form it could revive in the future). The second reason is that insofar as not only Maoism but also virtually all forms of serious socialism have disappeared, so too has their religious dimension. This leaves a space for religious revivalism of all sorts, not least of all various fundamentalisms, evangelical beliefs and the separatist nationalism that can accompany these.

I shall approach these larger matters by considering the views of several of the outsiders who were most important in framing, contextualizing and communicating the elements of this proto-religion, and most particular the Americans who became complicit in what I consider to be the transcendent dimension of Maoism. It is also a way of seeing how powerful this aspect of Maoism was at the time. For not all of these witnesses were so easy to convince; nor were they ordinary journalists. What they saw as facts on the ground led them to portray a Mao whose subsequent role virtually obliterated his early and more heroic phase. Indeed, it became ritually redefined: a papal, monarchical figure so given to fits and starts of ideas and reactions that in hindsight one tends to forget his claim to reveal truths not visible to most of his compatriots, whether on the left or the right. But there, at the right moment and in the right places, these witnesses not only saw a different Mao. They also validated Maoism itself as a form of redemptive power based on 'higher truths' that came to be self-validating, but without analysing the 'truths' in themselves. In this way they helped to establish the Mao mystique, especially in the early period, in Yan'an.

What impressed them most was less a matter of a Chinese variant of Marxism-Leninism than a sense of community spirit and collective agency. There was for them no particular apotheosis but rather a real Road to Damascus, and with it a sense of participating in a historical, moral moment. This was a moment when Mao's monopolistic truth claims seemed utterly plausible to them and commonplace knowledge seemed wrong - a space in which such truth claims were located and within which Maoism became both a social and political teleology, a doctrine of the exceptional source. ${ }^{3}$ In this regard I wish to show that one can consider the later Mao portrayed by Chang and Halliday as a case of 
Weberian political routinization of charisma, in which political violence becomes ritualized as a structural factor in the organization of power.

\section{Journalists as Witnesses}

That commentators can serve as witnesses is of course an old story. The literary reshaping of public understanding has an antique and classic pedigree. However, for professional journalists to serve in this role is relatively modern. Journalists are in this sense Johnny-come-latelies whose appearance is roughly coincident with the emergence of a popular press and the spread of literacy, as Benedict Anderson and others have pointed out (Anderson 1991). Putting the tools of the journalistic trade to such purposes may be said to have properly begun in the period just prior to the great democratic revolutions - British, French and American - when as on-the-spot observers, journalists became engaged in the ideological disputes of the time. The best of them were willing to take on the great debates, trade-offs between liberty and equality as well as ways to make power accountable and responsible, i.e. debates over the nature of democracy itself. In doing so they were often reviled and excoriated. Nevertheless they served as privileged witnesses to the events themselves.

The most successful of the journalists-cum-witnesses were those who could supply gripping eyewitness accounts of what they saw and from which they drew preferred inferences. They combined shrewd observations with if not comprehensive than comprehensible descriptions. Indeed, such an ability became the trademark of high journalism as distinct from mere reportage, the distinguishing mark of the serious journalist rather than the journalistic hack. This gave the former an aura, as Benjamin called it, a truth credential and well as a claim to right of access to the movers and shakers of the events themselves. In any case, by the time the major communist and nationalist revolutions of the last century occurred, such professional high journalism had long been established.

However, while revolutions might attract large numbers of reporters interested in the events for themselves, it was only the privileged few whose reportage achieved interpretive authority. Moreover, in the nature of the case, at any rate vis-à-vis the Russian and Chinese revolutions, interpretation meant contextualization, including exposing to public view the machinations of those in high places whose views they consid- 
ered blind and reactionary, not to speak of the role of special interests and corrupt politicians. ${ }^{4}$ In this sense these journalists-cum-witnesses acted as muck-rakers, missionaries and, above all, as interpreters. That is, they assigned to themselves the job of translating alien cultures into readily comprehensible understanding based on long sojourns rather than short visits. It is also the case that in general their analyses were quick, shrewd, intelligent and thin; that is, they lacked much intellectual depth. Not for them the dense distinctions of Marxist polemics and their philosophical underpinnings. Indeed, to become bogged down in such matters would have destroyed the ability of quick portrayal and the immediacy of descriptive impact.

In addition, remaining aloof from such matters went along with their notions of being independent-minded. These witnesses refused to be intimidated either by conventional views or by sectarian preferences. They regarded their observations as objective-a notion of objectivity that included partisanship as a means of rectifying widespread and prevailing distortions of fact and interpretation. In describing China as a place where justice had gone awry, theirs was also an appeal to a sense of fair play, in which objectivity required a rectifying partisanship, while bringing the two together was a badge of personal honour and professional pride.

If the persuasiveness of their arguments had significant effects on home consumption by making them stand out as opinion makers, they were also able to exercise some influence on governments and at times to serve as intermediaries between the existing powers and those trying to replace them. The latter was a role that could engender suspicion from both sides, which gave them an added incentive to protect themselves from charges of bias or inaccuracy or the dishonest exercise of their calling. They claimed the reliability of their facts. And they believed that in some final sense it was the terms of those facts that rendered it appropriate for them to address truth to power. ${ }^{5}$

The immediate journalistic predecessors and peers of these witnesses were those who had reported on the Russian revolution and its aftermath, including such figures as Walter Duranty of the New York Times (a Pulitzer Prize winner), Arthur Ransome of the Manchester Guardian, Albert Rhys Williams and Eugene Lyons, to name only a few. If not mentors, they were part of a larger radical pool which in terms of the Chinese revolution became identified in particular with Agnes Smedley, Anna Louise Strong and Edgar Snow. ${ }^{6}$ 
It should be clear that my present interest in these writers is not so much for their specific views or even their accounts of events, fascinating as these are. Rather my interest lies in the way their private access to Mao enabled them to give him a defining public stamp. Such private access was in effect their journalistic capital. And since it was a rare good and a scarce commodity, it was one they zealously guarded. It constituted a form of privilege that made them a part of the pantheon they themselves were describing. Evidence for such speculations is based on a rereading of their very abundant writings as well as accounts and comments of those who knew them in one capacity or another. In my case an interview with Harrison Salisbury led to an introduction to Helen Snow at her home in Connecticut. ${ }^{7}$ Although ill, she was nevertheless extremely voluble and appeared to be as committed ever to the China she knew in the old days. ${ }^{8}$ An interview with John Service led to Israel Epstein, whom I interviewed several times (in his rooms at the Friendship Hotel in Beijing). I was able to come to know such figures as Rewi Alley, Sol Adler and others who had thrown in their lot with China. ${ }^{9}$ Still later I came to know Edgar Snow's second wife, Lois Wheeler Snow. I interviewed many others who knew Strong and Smedley.

I select these three-Snow, Strong and Smedley - for discussion for several reasons. All three have been canonized in China, not least of all in terms of the 'Three S Society' whose president, Huang Hua, became foreign minister of China, but who in a previous incarnation was Snow's original interpreter in Yan'an (and whom I was able to interview in 1986). ${ }^{10}$ It is also the case that each of these 'witnesses' to Mao's revolution has been written up in extremely useful biographies (Hamilton 1988; Strong 1983; MacKinnon 1988). In addition to their books and articles, there are abundant archival materials. However, if we concentrate on these three it should be kept in mind that they were only a part, albeit a very significant part, of a much larger circle of foreigners favourable to the Chinese communist revolution, many of whom were their friends and associates.

Since the three have been written about on many occasions, there is little need in this discussion to go into details about their lives and works. They represented only a fraction of a much larger and very diverse group of reporters and commentators who began arriving in China in the immediate aftermath of the First World War to find plenty of political ferment.

The May 4th movement inspired a whole generation of young Chinese intellectuals to engage in political activism, and there was widespread 
urban and labour unrest. The inheritance of Sun Yat-sen, which for a time had seemed capable of providing within the GMD a framework that could embrace both the nationalists and the communists, had become the provenance for internecine conflict. So much so that willy-nilly in order to do their jobs in more than a perfunctory way, journalists had to choose sides. As factional disputes intensified, partisans on the left saw Chiang Kai-shek becoming more and more proto-fascist while the Maoist version of communism with its agrarian communalism seemed by far the more promising alternative and a radical departure from Stalinism. As the GMD Northern Campaign to eliminate warlords was succeeded by extermination campaigns against the communists, the hinge or defining event became the now famous Long March - the ultimate dramatistic accomplishment (and which in Chang and Halliday's reinterpretation was nothing of the sort since they were allowed to escape by the GMD).

Smedley, Strong and Snow and their friends and associates saw this event as a more or less miraculous event, one that recast the Chinese communists not as a band of bandits but as heroic survivors who, when they finally holed up in caves in Yan'an, founded the New Jerusalem of the Chinese revolution. Mao became something of a Robin Hood with brains, his writings serving as critical guides to military and civic action. Moreover his emphasis on the peasantry as a class with revolutionary chains had a romantic resonance with an earlier American heritage. Mao himself could be recast as someone reminiscent of populist agrarian reformers in the United States. But he was also a self-made intellectual carrying forward the Marxist-Leninist-Stalinist pedigree on his own terms.

As to the events Smedley, Strong and Snow witnessed, they were intrinsically dramatic enough, both in their details and in the round. To pursue them as facts and turn them into stories and narratives requires in the first instance great physical personal courage not to speak of endurance. All three witnesses were tough, restless and always on the move. They were continually on the look-out for the interesting personality, the tragic hero, and made such people metonymic for the larger principles of the revolution. By the same token they were romantic realists living for radical adventure, their accounts all the more gripping for including themselves. All were good writers.

Smedley, a self-made woman born to poverty in the West who had absorbed populist radicalism from the start, described incidents of murder she had witnessed first-hand, not to speak of assassination, torture and 
rape. China for her had abandoned all pretence of decency. Its political and social institutions had become totally corrupt. She was appalled at the general indifference to the cruelty and brutality of ordinary life, where death and torture had become banal and ordinary. And she was mesmerized not only by Mao himself but the Chinese communist top leadership, some of whom she came to know intimately. While she wrote as a professional journalist, she had come of age as a radical in the context of the Indian struggle against British imperialism and in the particular context of Indian exiles in Germany. As a result of this experience, she became what she remained: a professional revolutionary writing largely for German and American newspapers. Although for a time China correspondent for the Manchester Guardian, to her great frustration she couldn't get a word in edgewise at the Daily Worker.

Anna Louise Strong's Letters From China were widely read in the United States and England and were said to have influenced Eleanor Roosevelt and other highly placed figures. Her articles and books were disseminated widely in the American press. She was the most intellectual of the three, with a doctorate from the University of Chicago. Her roots were in New England Congregationalism. As she became involved in social work in the United States, she moved more and more to the left, coming to know the more Bohemian left in New York as well as communists. She, perhaps more than the others, was most firmly convinced of the doctrinal rightness of communism.

But it was Edgar Snow who gave his stamp and imprimatur to the Chinese communists first in Bao'an, where he first interviewed Mao, and then in Yan'an. He wrote regularly for the Saturday Evening Post. Perhaps no single book was more influential in China as well as the United States than his Red Star over China (first published 1937), which remains something of a landmark even to this day with its unforgettable portrayal of Mao.

If Smedley was flamboyant and Strong demanding, Snow remained the 'man from Missouri', who kept a certain distance while never pretending to be an indifferent observer. By presenting the 'Reds' in a benign way, he countered the prevailing view of them as bandits. All three writers remained admirers of Mao to the end of their lives. Smedley died in 1950 and so did not have to confront the twists and turns of the party line that began with the Great Leap and the anti-rightist campaigns. The other two did come to have reservations about the intemperateness of the Cultural Revolution, particularly Snow, who in his obituary of Mao comments that the leader 
could simultaneously hold in mind contradictory concepts of time and space, of strategy, of right and wrong; he could act out decisions into realities as if they were the only truth, knowing all the while that the opposite was an essential part of it. (Cited in Hamilton 1988: 285)

Throughout the 1930s each of them opened a somewhat different window to the radical side of Chinese politics. Their views encouraged young Chinese to join the Chinese communists rather than the Guomindang. Their opinions on Mao's communism were voiced in redeeming terms: a relatively open community, locally democratic, honest and egalitarian - in short, everything that China was not. As indicated, they remained aloof from the intricacies of Mao's texts and the exegetical details of wording and meaning that became so much a part of the politics of theory and the theory of politics and, above all, Mao's rationale for action. They preferred the high road in every sense, that is, they were longer on heroics than the ins and outs of ideas other than in the most limited way. ${ }^{11}$ They combined in their narratives a very American view of politics as a struggle for morality, the good versus the evil and as a result captivated a quite considerable readership.

They also rubbed shoulders with some of those who had come to China on official missions and who became attracted to what they saw going on Yan'an in sharp contrast to the rest of China. That wider circle of witnesses included clerics, like the so-called 'pink' Bishop Logan Roots, a few members of the American military like Colonel Evans Carlson (of Carlson's Raiders fame), and General Joseph Stilwell. ${ }^{12}$ Other journalists included Israel Epstein, who was a correspondent for the United Press and Harrison Salisbury for the New York Times. ${ }^{13}$ And there those who chose to cast their lot with the Chinese communists in working for them, some well before and some after the communists came to power, such as Rewi Alley in the first instance and Sol Adler in the second.

What then drew these people to each other? While each had his or her own reasons for going to China, all saw the revolution as a fundamental break, a disjunctive moment, one that defined a 'before' and an 'after'. 'Before' was all nasty, brutish and short, while the 'after' remained a promised land. For them Yan'an embodied an ideal concretized in a practical revolutionary programme, one that seemed the only plausible solution to China's chaos and suffering. Whatever their particular views, they witnessed in Yan'an a community that through its mode of activity appeared to be capable of transforming what was negative into something socially and politically positive, evidence for the latter provided by the success of the social reforms practised by the commu- 
nists on a more or less daily basis. Above all, the transcendence of Mao seemed something of a miracle in its own right, not least of all by the circumstances of his origins. The Mao they came to know and admire was the agent of a higher revolutionary consciousness and not just a superior political leader - in short a cosmocrat. One hesitates to use terms like idolatry; Mao's mystique was for them never that. But mystique he certainly had, although they toned this down in their accounts.

In hindsight one can only speculate about how much they actually knew of what was going on despite their mastery of events and their extraordinary access to leaders and commanders at all levels. One can only speculate too, about what they were willing to hide or at least what they preferred not to see. ${ }^{14}$ However, it seems quite clear that the Mao they knew in his Yan'an heyday was not the same Mao they saw emerge after coming to power in 1949 and especially during the Cultural Revolution. ${ }^{15}$

I have mentioned the seductive aspect of personal access to Mao and his immediate entourage. They regarded him as a mover and shaker of history in the fullest sense of the word, that is, in terms not only of China but of the future impact China would have on a worldwide scale. Such views only intensified the value of access to and intimacy with Mao himself. Conscious of their roles as witnesses to high historical drama, they saw the entire atmosphere, physical and well as moral and practical, in terms of narratives and theatre, of which they were a part.

This sense of theatre is present even in Snow's original interview with Mao in Bao'an. His description is stage set and setting. Even the idea of audience took on the character of ritualistic journalistic pilgrimages. It was a special occasion to interview Mao, to hear his words, and not only to see but also to come to know the palpable living Mao face to face. Such access to Mao was more than a valuable journalistic privilege; it was entry into the sanctuary.

Of course, this did not prevent the witnesses from taking advantage of their access in different ways: Smedley to promote feminism in an age when it was just beginning; Strong to clean up the unpleasant side of communism of which she herself had ample experience in the Soviet Union (not least when her Russian husband was purged); Snow in trying to make sense for outsiders of what was going on in China outside of the conventionally held views. Each in exposing different aspects of conditions in China nevertheless shared a common and firmly held conclusion: Mao's version of communist revolution was not like any other version and it was historically necessary. They also tried to make their 
accounts and conclusions palatable to publishers and the public at large. Hence the claims that their views were not ideological but assertions of fact over opinion. They portrayed themselves as individualists if not 'characters', recognizable within the tradition of forthright independent journalism in the classic American mode. ${ }^{16}$ All had authentic American pedigrees. ${ }^{17}$ But all retained a special affection for Mao himself. For Strong, this was explicit: 'I came because Mao in Yan'an invited me to return and because ever since I met him I felt that the answer to the world's revolution was here. ${ }^{18}$

Despite such convictions, and in the case of Strong, residency in China, both Smedley and Strong retained a certain nostalgia for the United States. If the latter remained constant to communism, underlying her devotion was principled action - to enable good works from a radical missionary position. ${ }^{19}$ Each believed that his or her own dissent from mainstream views represented an obligation to the Chinese people (for Smedley, the Chinese 'masses'). All three at times marched with the Red Army. They provided medical care for the wounded. They gave money to help individuals on the ground. That active service component of their commitments was key to the access they obtained. Yet despite such commitments, which on the whole were quite open, they were able to a surprising extent to maintain links with diplomatic circles and ambassadorial contacts.

Smedley and Strong came to the Russian and Chinese revolutions as rebels who had already discovered causes. Edgar Snow had fewer predispositions. But he moved in circles where nationalism, socialism, anti-imperialism and anti-capitalism were the ordinary subjects of intense debate among those who defined themselves and each other according to which symbols of communism they preferred - Lenin, Stalin or Mao - (and more occasionally Trotsky) and how they felt about their corresponding lines, fractions and ideologies. If there was a previously defining event for them all it was the Spanish Civil War. But as well each stood for a more general set of conditions of possibility - dictatorship or democracy; private property or public; freedom rather than coercion.

Anna Louise Strong, more than the others, viewed the Chinese communists as a modern version of a pervasively American kind of Christian millenniarism stripped of its clericalism. Agnes Smedley saw in revolution the best way to shake up inequities of all kinds, those produced by imperialism, sexual and gender inequality - revolution as a thing in itself. Edgar Snow saw the revolution as a reaping of the whirlwind given the suffering, corruption and cruelties that prevailed. All believed that 
conditions in China were the result of imperialism, foreign and domestic, the most raw form of compradore capitalism, or to use Mao's words, 'the patriarchal class of local tyrants, evil gentry and lawless landlords [that] has formed the basis of autocratic government for thousands of years and is the cornerstone of imperialism, warlordism, and corrupt officialdom.' In a subsequent generation they would be followed by those who were not only true believers but cultists, some of whom, knowing nothing of China, would be mesmerized by the Cultural Revolution. ${ }^{20}$

For Strong and Snow as well as a good many others the Cultural Revolution occurred towards the end of their lives as working journalists. It gave rise to reservations about Mao that coincided with the decline of their own influence in the United States. During the McCarthy period they were branded as traitors. But something of the faith remained until the end. Smedley, who had died much earlier in England, had established something of a precedent when her ashes were taken to China and buried in the Cemetery for Revolutionary Martyrs. When Strong died in China, her funeral was attended by Zhou Enlai, a large black banner displaying the words, 'May Anna Louise Strong Live Forever in Our Memories'. She too was buried in the Cemetery for Revolutionary Martyrs. Snow, in self-imposed exile in Switzerland, was able before he died to intervene in public affairs in an extraordinary way. He played a crucial role in arranging President Nixon's visit to China (Hamilton 1988: 280). ${ }^{21}$ His ashes were divided between a site overlooking the Hudson River and the Lake That Has No Name on the campus of Peking University.

As witnesses to revolutionary events, these commentators supplied their own testimony and provided authenticity to belief and credibility to preferred truths. They expressed those truths as outrage-outrage at conditions as they saw them in China, outrage at the violence and corruption of the GMD, and outrage at American support for it. In defining in a public and visible way what was wrong, and not only wrong but morally wrong, and describing in concrete ways the suffering this imposed upon ordinary people, they defined what can be called a negative pole in which Maoism became the overcoming project. What they saw as witnesses became a form of testimony, in which they offered themselves as evidence for the evidence. Such political audacity was always a dangerous game. They were in one sense incorporated in the Chinese communist movement; so much so that their lives remained intertwined with the triumphs and vicissitudes of Mao, even when his activities and the turbulence it set off troubled them. 


\section{Yan'an and the Religious Moment in Revolutionary Politics}

The extent to which the witnesses contributed to the transformation of Maoism into a radical sect within Chinese Marxism should not, of course, be overstated. Their roles were in no sense decisive. What happened in China followed its own dynamics. Nevertheless, in describing Mao's role in reshaping the Chinese Communist Party, and the actual events of war and revolution, the picture they portrayed was to some extent a picture invented by Mao himself. In doing so he placed himself at the political centre of the party, within the territorial space of Yan'an as a simulacrum for China as a whole-a miniaturization of a redemptive redoubt, civil and military, in which teaching and preaching combined in hortatory texts. The themes were explicitly moral in terms of millennial Marxist solutions, nationalist in terms of transcending redemptive and libertarian themes, plus the high drama of violence, heroic acts, the individual overcoming the self by reaching to a collective apotheosis.

These comments should not be misunderstood. Even though one ought not equate religion and politics, they have at times certain propinquities if not properties in common. On this there is a huge literature, more of it dealing with religion as politics rather than politics as religion. Among the characteristic properties of the latter is the deification of political leaders who demand obeisance and command respect: charismatics who can take many roles and play many parts whether monarchical, priestly, military or civil. What they have in common is a set of omnipotent beliefs, revelatory or theoretical, which are extensions of their own special patrimony. Such beliefs have political consequences, whether secular or sacred in origin, including the mobilization of clienteles, claims to sacred territorial space, privileged affiliations, cultural identities, loyalties and commitments (Cohn 1961; Callois 1959). In this sense such figures play larger-than-life roles in history.

In this more general sense, too, few would doubt that Marxism in several of its putative forms shares similarities with religion tout court, even and perhaps because it is explicitly anti-religious. On this score there is plenty of evidence about the religious properties of communism. As one former devotee, Arthur Koestler, put it with respect to the Soviet Union:

Russia was merely the new occasion for the revival of an archetype as old as humanity. Like its past symbols, the Golden Age, the Land of Promise and the Kingdom of Heaven, it offered glorious compensation for a life of 
frustration and the pointlessness of death. Those of us who have lived in the communist movement know how completely the Soviet myth fulfilled this function - not for the Russians but for the worshippers outside. (Koestler 1945: 125)

Or as Sheila Fitzpatrick put it:

Like freemasons, communists had many rituals. Their status as communists was related to their mastery of esoteric language. They were brothers and their brotherhood was in some sense secret. They had symbols they cherished, like the Red Flag, and a history, including a martyrology, that every communist had to know. They had a body of sacred texts ... (Fitzpatrick 1999: 19)

The witnesses in their writings and dispatches gave substance to this larger frame. The experiences they chose to describe matched Mao's own discourse not in form but in descriptive characterization such as themes of descent: how far the Chinese people had fallen and thereby come to inhabit a kind of nether world, a virtual hell on earth. These themes set the stage for their opposites, themes of accomplishment, miraculous military victories and social triumphs. Yan'an was the special metaphor, the living version of an idealized community, a microcosmic salvational universe which gave a virtual superhuman dimension to what Mao was able to achieve against overwhelming odds, providing testimony to the rightness of his logic and the correctness of his vision (Frye 1976: 97-126).

In this sense they served, and willingly, to define the Chinese revolution as a combination of founding and transformation, the birth of a new society based on a total and totalizing revelatory metamorphosis. This morally redemptive transformation would change the attitudes and commitments of the Chinese from a passive acquiescence in things as they were, an acceptance of chaos as a normal condition, to commitment and self-sacrifice for the common good. The witnesses lent their aura to Mao's definition of the revolution as a truly historical disjunctive moment rather than a civil war and national response to Japanese aggression.

In this sense also the witnesses gave a certain universality to the events happening in China. Their writings suggested that all such movements require certain conditions if revolutionary actions are to be successful by means of mass mobilizing organization. A negative pole is needed in order to define the transcending accomplishment, the projective outcome. That pole represents that period of revolutionary latency, that condition of chaos, of generalized risk, that opens the way for the 
kinds of disjunctive moments described, and invites authority. The intermingling themes and contexts included those relevant elsewhere: the founding of new nations, the transformation of old ones, and the redemptive recuperation of those gone astray. All require the mobilization of transformational energies as a way to accomplish both goals. For the witnesses the way the Chinese communists accomplished that mobilization of energies, individual and collective, represented the necessary if not the sufficient Promethean conditions, to achieve something akin to a political Promised Land. In this they helped to construct what can only be called the mythic dimension of Maoism.

It is in these terms that classic Maoism shared many of the attributes of religion. It was also a product of Mao's cosmocratic capacities as Chief Agent requiring absolute obedience to his monopolistic claims of truth. Other views were not dissent but heresy, a common feature of religions generally and politics more particularly, especially when different factions claim competing orthodoxies, with each trying to capitalize on any loose estrangements by followers of the others. In the Chinese case, dissent over doctrines within the CPP intensified internal conflict and sect division in the very act of demanding total unity and a common front against common enemies. ${ }^{22}$

I have elsewhere argued that Yan'an was a discourse community with something of a Chosen People quality. In present terms the Yan'anites represented a semi-religious community complete with its own biblical texts, its glossators and commentators, its official interpreters and its ascetics - asceticism being a requirement of being a 'good communist'. This defined the 'inside' which contrasted with the 'outside' in China as a whole. Not only could nothing in the rest of China compare with the disciplined social life of Yan'an, but in this rugged terrain one found the cultivation of the arts, theatre, culture and education. Its rigorous morals gave an appearance of equality between men and women. As for struggles between elements of the party, facts on the ground seemed to vindicate Mao's line. So impressive were his accomplishments that it was difficult not to come under the spell of Mao's vision, his ability to see past the limits of conventional wisdom, and to give events new meaning, if not turning facts into fictions and fictions into facts.

The witnesses, then, accepted the events of struggle in terms of the logic he stood for without going into that logic in any detail. For them it appeared uncanny in its shrewdness. And if it seemed to spring from his own head, it also represented an extrapolation from the common experience (Apter and Saich 1994). In sum, the Mao they came to believe 
in was the Mao who was a master at converting events into situations, and using such situations as the structural components of his texts and his interpretations of history. He knew which situations to identify and which among them would make people sit up and take notice. He was in these respects expert at establishing promontory situations in which defeats became victories: the Battle of Jinggang Mountains, the Nanchang Uprising, the Autumn Harvest Uprising, the Long March itself, the Battle of Luding Bridge, becoming like so many Stations of the Cross. These became key events in a narrative that endowed Mao himself with symbolic significance and provided a logic for millennial outcomes. It became the task of the witnesses to provide confirmation, indeed apostolic testimony. All religions properly speaking have their equivalents.

They believed too that Mao's authorizing sources derived not only from Marxism but included an earlier interest in anarchism, something particularly appealing to Smedley. But because Mao also drew on those with authorizing historical resonance, Confucianism and Taoism (with perhaps a touch of the Taiping leader Hong Xiuquan with his visions of God, and whose texts had to be learned by all) as well the grand and subversive transformations between dynasties, he drew on 'authentic' Chinese cultural traditions (Schram 1989: 141; Wakeman 1984). Mao was able to bring these down to earth and a straightforward version of dialectical knowledge, a logic of contradictions perhaps more than a true dialectic, and a notion of class struggle by means of which he stood orthodox Marxism on its head. The redemptive projects he defined were grounded in the peasantry, making them the inversionary surrogates for revolutionary action and appealing to the weapon of transformational accomplishment. So, if the goal was inspirational, its authority dialectical, based on a reading of history as an evolution of inversionary stages, its consequences were entirely practical. The party was the chosen instrument for a chosen people whose enlightenment principles constituted the moral and political centre according to Mao - principles that abjured liberalism and tolerance in the name of a higher Reason. ${ }^{23}$

Mao carved discourses out of events, just as in Yan'an they carved caves out of the mountains. Not only were the witnesses fascinated by Mao close up, they also recognized a certain peasant shrewdness that linked him to and made him part of the rank and file. But they appreciated too his more sophisticated, if stylized, knowledge of art, literature and calligraphy, which played well with the intellectuals in the movement. They liked the way he could play several ranges within the same textual register, to make himself as much revolutionary commander as 
teacher. They found his style as well as his virtuosity endearing. For them Mao was their folk hero of socialist modernity, his self recruited elect an 'Onward Communist Soldiers' equivalent of the missionaries of an earlier day. Reason replaced simple belief (or so it seemed), within a movement-militant instead of a church-militant. Although they would have most emphatically disavowed such a comparison, one could argue that at the very least during the Yan'an days, the witnesses saw in Mao something more than an exceptional reformer, or even a prototypical revolution. They recognized a figure vaguely reminiscent of a primitive Jesus, not only a man of the people able to perform battlefield miracles but also a man of organization and ideas, someone of whom it could be said that

he regarded himself as the universal reformer. The heavens, the earth, the whole of nature, madness, disease, and death, were but his instruments. In his paroxysm of heroic will, he believed himself all powerful. (Renan 1927: 151-52)

The quote, ironically enough, is from Renan's Life of Jesus. If this seems far-fetched, all one needs to do is go back to Edgar Snow's description of Mao. He portrays him as a man of the people, a man of sorrows acquainted with grief, a cosmocratic agent expressing doctrinal moral truths. Renan's purpose was to examine the real rather than the apocryphal aspects of a figure whose hortatory preachings were realized in a mystical community, exegetically bonded, and representing a redemptive and redeeming project. And if the Apostles described the magic of the events, their writings constituting biblical texts, the Gospels giving rise to hermeneutic endeavour, truths pored over intently by a priesthood capable of establishing both a method of moral persuasion and an insight into privileged truths, so too with Mao's texts and their interpreters - the whole reinforced in Rectification Campaigns that served to both endorse and punitively enforce Mao's exceptional revelatory insight. ${ }^{24}$

Not only did the accounts of the witnesses contribute to such myth making but also in their narratives, as in Mao's, it was the Mao himself who became the central authorizing figure, the knowing prophet to whose original thoughts the witnesses offered testimony and context, and by so doing privileged his role. If what Renan described could apply more generally to saints or prophets, popes and bishops, fetish priests and shamans, mullahs and monks, and not least of all to political philosophers and their doctrines, one could also argue that the real Mao was a bit of all these. 
Insofar as Yan'an represented a revolutionary moment, another of Renan's comments also applies:

'Our civilizations, governed by minute restrictions, cannot give us any idea of the power of man at periods in which the originality of each one had a freer field wherein to develop itself'. (Schram 1989)

The Yan'an that the journalists saw was one of those periods. It was an opening, one with not only sinified characteristics of Marxism but in the eyes particularly of Smedley, Snow and Strong, a moment that paralleled the early Christian communities. Like them, the constituency was of the poor. Like them followers were persecuted for the revolutionary content of their beliefs and principles. And like them, the revelatory was connected to the instrumental. Revolution was the necessary disjunctive accomplishment-not any disjunction but a revolutionary break with previous beliefs and institutions.

The witnesses also realized that such historical moments are rare and that when they occur it includes personalized expressions of power - political agents purporting to totalizing salvational solutions. Insofar as agency is crucial, so the return of the exiled Mao, this time to power in the party, made him the epicentre of a Rome towards which all roads would lead, not only on the ground but in more general ways - symbolic, institutional, communicative and instrumental (Ricoeur 1986: 235).

Perhaps in retrospect it is better to describe the beliefs of the witnesses as a 'now you see it now you don't' phenomenon. Certainly our witnesses attributed Mao's power to the effectiveness of his appeal to the deprived, marginalized, vulnerable peasants who appeared to possess the best revolutionary potential as surrogates for Mao's hortatory lastshall-be-first, world-turned-upside-down, master-and-slave doctrines. They found themselves in a position that would later find resonance in nationalist and social protest movements, revolutionary and redemptive in nature (Apter 1963). Nevertheless, just as a church is a venue for ordinary social occasions, the human intimate side of doctrinal orthodoxy, so for them Yan'an remained something of a church in that sense, and on a human scale, as was Mao himself. In this regard there was something deliberately endearing about the way both Smedley and Strong liked to recount how they taught Mao to dance and how dancing become a regular event at least for the highest cadres.

The religious aspects of politics also create the conditions and characteristics of high drama with recounted events as dramatic episodes. Snow in particular was sensitive to the drama associated with Mao's role. Just before recounting his interview with Mao in Red Star over 
China, he discusses the importance of 'red theatre', linking it to a larger radical inheritance, including the revolutionary theatre of the Soviet Union. As already suggested, Snow's portrayal of Mao is itself theatrical. His interview begins with a descriptive stage setting. He and Mao are huddled in a cave lit by sputtering candles. Mao speaks in a 'soft southern dialect' of his origins in a poor peasant family, the strictness of his father, his love of Chinese classics, his going to work at the age of 13, his apprenticeship, his return to school in ragged clothes, his awakening to radical thought, and later, his internal exile by the party to Hun'an, where he found inspiration among the peasant poor. Snow's account shows a Mao whose personal fortunes became an overcoming project, overcoming ignorance, poor social conditions, the contempt of intellectuals, etc. for China. The story as he told it is by now well known (Saich 1996; Rue 1966).

What the witnesses above all tried to portray was a Mao whose rise to power was not only a matter of skilful maneouvring but also an example of virtue triumphant. In this they provided a rendered offering, virtually a biblical tale. And while

[t] here would never be any one 'savior' of China, yet undeniably one felt a certain force of destiny in Mao. It was nothing quick or flashy, but a kind of solid elemental vitality. One felt that whatever there was extraordinary in this man grew out of the uncanny degree to which he synthesized and expressed the urgent demands of millions of Chinese and especially the peasantry. (Snow 1984: 66)

It should be noted that of the three, Edgar Snow always kept something of himself in reserve. ${ }^{25}$

What the witnesses saw with considerable clarity was that Mao's exceptionalism was due not least to an uncanny ability to combine a life intertwined with action, not to speak of violence, with symbolic and logical nuance.

Unless social life has a symbolic structure, there is no way to understand how we live, do things, and project these activities in ideas, no way to understand how reality can become an idea or how real life can produce illusions; these would all be simply mystical and incomprehensible events. (Ricoeur 1986: 8)

Such symbolic structures realized in the acts of individuals are what Snow describes in terms of individual experiences - how joining the revolution became something more than an ordinary rite of passage and more like a religious conversion, an induction into Mao's army of believing militants by means of which personal insight was achieved. 
This made it possible to transcend the self by means of commitment to prescribed truths and beliefs, not in some intellectual way but biblically; that is, making them resonate throughout one's entire being.

It was Mao's ability to analyze the experience common to his generationrather than the uniqueness of his own experience - plus his messianic belief in the correctness of his own generalizations of that experience, which distinguished him from compatriots who became his followers. (Snow 1970: 165)

It was in these terms that able journalists were able to persuade themselves that Mao's was a version of agrarian communism, and that Yan'an was socialism with a human face. ${ }^{26}$

In sum, the witnesses made more credible those aspects of Maoism that share attributes of religion, including the cosmocratic capacities of its agents and the monopolistic claims of its truths, which define other views and beliefs less as dissent and more as heresy. This last is particularly important, especially when different factions claim competing orthodoxies, each trying to capitalize on any loose estrangements by followers of the others.

\section{The Cultural Revolution and the End of Any Existing Socialism}

In these terms one can say that Mao had not one but two periods of 'ascendancy': the first in Yan'an, especially during the years 1938-42 and subsequently the Cultural Revolution, the latter both farce and tragedy. If the two events are hardly comparable, Snow and Strong, not to speak of other witnesses, certainly did compare them, and at first with sympathy both for Mao's effort to regain power and also because they took a dim view of the economistic turn the Chinese government had come to favour. For example, in Red China Today Snow wrote that

Mao was personally revered by most of the peasants of China and had gone far toward winning the younger people to his banner; the Cultural Revolution had, in the people's eyes been necessary to prevent the formation of a corruptive (revisionist) elite; and Mao had behind him the loyalty of the armed forces sufficient to handle the internal factors of disunity. Mao still held the 'mandate of heaven'.'

Snow goes on:

It was instructive to note that whereas in Stalin's Russia such a power struggle could have been quickly decided by the liquidation of any comrades in 
opposition, that did not happen in China. Despite three years of a great purge, Liu Shao-ch'I alone was officially named as a renegade and expelled from the Party by Mao's Central Committee ... For the rest of the top revisionists there presumably remained some hope of rehabilitation. As in past rectifications efforts at reconciliation followed tension and struggle.

And even more astonishing:

Whatever their genesis, the new organs of Chinese government were bound to uphold the Thought of Mao as a unifying faith. Once the Soviet Party had repudiated Stalinist ikons, the Chinese could no longer involve the authority of Moscow's infallibility. After 1953 even Liu Shao-ch'I could not but help glorify Mao as the personification of revolutionary creativity, independence, national self esteem, and world prestige. Now, as throughout history, China put a unique Sinitic stamp upon an imported ideology which at first had appeared, to many, as a kind of barbarian conquest. It was not by accident that the patriarchal Mao, depicted as the Red Sun, hailed his people from the Heavenly Peace Gate where the Son of Heaven presided for ages long predating Karl Marx. (Snow 1971: 35)

For all that, the witnesses did begin to have doubts. The question is, what kind of doubts? The problem of evaluating their belief in these terms is, as I suggested at the start, due in part to very real differences between religion itself and its political version, with religion more able to remain self-sustaining and self-replenishing, while over time political religion becomes ritualized, empty and punitive. Eventually this was an aspect of the Cultural Revolution that Strong and Snow among others could not continue to ignore.

For all their commitment, and despite their view of Mao as Redeemer, it was the practical side of collective action that most appealed to them. They were all very much in the 'learn by doing' tradition. They were believers in Maoism as a system that produced collective voluntarism, which on a day-to-day basis is what a good deal of religion is about. But eventually even they were increasingly disturbed by the way the Cultural Revolution converted the Mao they knew in Yan'an into a strange, alienating, indeed almost fantastic creature of virtually mythic proportions. In place of the Mao they knew, who they recognized had his limitations, they saw in his return to power a condition that detracted from that original shrewdness, tactical sense and timing that had brought him to power-qualities that had been much underestimated by his competitors within and outside the party, not least of all by the Soviettrained 'twenty-two Bolsheviks' to their infinite regret. The witnesses also recognized that, in keeping with their own beliefs as opposed to the more philosophically inclined Marxists, Maoism was not a very 
deep form of Marxism-Leninism, but because of that it was accessible to most people at some level. So, while Mao was a remarkable figure of enormous talents, he was neither a superman nor the all-seeing omniscient figure he was portrayed to be in the Cultural Revolution (Schram 1969: 171-222).

Nevertheless, for a considerable period of time Strong and Snow publicly acquiesced. For them, like a good many others, the Cultural Revolution appeared to be necessary because Mao had lost power to those who would corrupt the revolution. Strong, by now a more or less acceptable relic, allowed herself to be inducted into a group of Red Guards and wore a Red Guard armband on her uniform, although she did express misgivings that things had gotten too much out of hand.

Only very slowly, and well after the advent of the Cultural Revolution, did these witnesses and their associates begin to distance themselves from Mao. But it was with great reluctance and such views remained private. Publicly they were unwilling to admit that something was going terribly wrong. Worst of all they began to realize that the apotheosis of Mao could not have occurred without him wanting it. They saw in such idolatry a dangerous if not fatal attraction to political leaders in other countries trying to emulate and exploit an equivalent phenomenon: Nkrumah's pan-African second coming in Ghana had its little black book; the Peruvian revolution its little blue book; and even Colonel Quaddafi had his little green book (Apter 1963).

Nor could they see the renewal of Yan'an principles in the events of the Cultural Revolution as claimed by its protagonists. They were particularly disturbed that by elevating Mao to god-like proportions, he was becoming a larger-than-life caricature of himself - such levitation resulting in a Mao ever more remote and inaccessible to the people themselves. ${ }^{27}$ Snow wrote more explicitly of the new role of the 'Chairman', the cult of personality and the 'immoderate glorification' he witnessed:

Giant portraits of him now hung in the streets, busts were in every chamber, his books and photographs were everywhere on display to the exclusion of others. In the four-hour revolutionary pageant of dance and song, The East is Red, Mao was the only hero ... I saw a portrait copied from a photograph taken by myself in 1936, blown up to about thirty feet high. It gave me a mixed feeling of pride of craftsmanship and uneasy recollection of similar extravaganzas of worship of Joseph Stalin seen during wartime years in Russia. (Snow 1972: 68-69)

One suspects that neither his misgivings nor his 'pride of craftsmanship' ended with the portrait. 
If Snow and Strong as well as others continued to be great believers in calling a spade a spade, they did this best when they were comfortable reporting what they saw. When what they saw became uncomfortable, they became confused and unsure of themselves. They wanted above all to maintain their faith in the fundamental rightness of the Chinese revolution. They pointed to its visible accomplishments and obscured its disasters. None would have favoured the China of today. They were anti-consumption if not anti-capitalist. They liked the ideas of communal farming, Indusco, the industrial cooperative, which Rewi Alley and Helen Snow had helped to establish in the early days. They preferred the intimacy Yan'an afforded. Indeed, what they wanted was nothing less than the small community in the large, hoping that the contradiction in terms could somehow be overcome. Theirs was then a kind of internal and hesitant revisionism. So at the end they in fact refused to call a spade a spade.

But there was another and deeper reason for their discomfort than the idolatry with which Mao had become endowed, and that had more to do with belief and less with particular practicalities. If one follows the line of separation between religion and political religion in terms of their relative capacities for moral replenishment, religion appeals to the hereafter, its days of reckoning are salvational. There is no final groundlevel denouement. Not so with political religion, which at some point has to show results. Moreover, if the moral claims have been placed higher than the stakes, even the best political results will be found wanting.

In China Maoism, insofar as it became a political religion, for all its practical revolutionary accomplishments, lacked staying power as a belief system. The Cultural Revolution was among other things an effort to reinvigorate and revive its religious side, using the myth of Yan'an in the process, its very rusticity and primitivism being a crucial part of its revolutionary charm, especially to outside observers. It failed not only because political religions fail in such endeavours but also because Yan'an never was and never could have been a blueprint or a model for a modern state. In the end Maoism failed as political religion not least of all because of the practical tasks of eradicating illiteracy, poverty and corruption endemic in China and making ordinary life easier required practical efforts at reform rather than drastic swings in the party line and hortatory and visionary appeals that only compounded the disasters. It was precisely in order to compensate for the latter that market reforms made the most sense - a solution that was anathema to Mao and his old guard associates precisely in religious terms - as apostasy. 
In these regards the contrast between Yan'an and the Cultural Revolution could not have been greater. ${ }^{28}$ Nor is it so surprising the latter virtually destroyed all those who had played important roles in Yan'an, pulling each one down from the heroic pantheon in the name of revolutionary renewal even as it proclaimed itself the Second Coming, the renewal of Yan'an itself. Whereas in Yan'an Mao's writings, texts and speeches were pored over for their meaning, resulting in a form of exegetical bonding similar to that of a religious body, in the Cultural Revolution his excerpted sayings, especially those incorporated in various versions of the Little Red Book, became revolutionary boiler plate. ${ }^{29}$

Mao's reassertion of power was thus accompanied by canonical redemptive fantasies, the effects of which produced political, social and economic chaos. What may have started as a way of jumping generations in order to counter the growth of a bureaucracy increasingly secular, pragmatic, growth oriented and indifferent to Mao resulted in a dictatorship of such fanciful proportions that well before Mao died, China was plunged into deep and profound ideological estrangement. One outcome of which was to make possible the very outcome Mao opposed-China totally preoccupied with growth, development and willing to employ capitalism for highly concrete and pragmatic ends (Tsou 1986). Such matters have been more than sufficiently documented and need no further recounting. In hindsight, if in its first coming Maoism was the most successful Marxist variant of radical political religion, in its second it was the least (MacFarquhar 1974).

Schram's conclusion is that Mao's political role was essentially ambiguous:

Eternal Rebel, refusing to be bound by the laws of God or man, nature or Marxism, he led his people for three decades in pursuit of a vision initially noble, which turned increasingly into a mirage, and then into a nightmare. Was he a Faust or Prometheus attempting the impossible for the sake of humanity, or a despot of unbridled ambition, drunk with his own power and his own cleverness? (Schram 1989: 206)

He suggests that he was a bit of both.

I would go further. In my view the surviving witnesses hoped that the Cultural Revolution would serve as only as an unfortunate political spasm in the long history of China. But I think they had caught a glimpse of something much bigger than that, something that if grasped at all they certainly did not want to discuss or come to grips with - that the Cultural Revolution itself prefigured a dying socialism. This is something that at the end Mao must have realized even more than the witnesses. 
How else to explain the sheer desperation of his final gesture to stave off the inevitable - an inevitable which if it succeeded would reverse the doctrinal inevitability of Marxism in all its forms? In this sense the Cultural Revolution was a dress rehearsal for what would happen to the rest of the socialist 'camp'.

The late Mao had few dialectical accomplishments. The Cultural Revolution was a last testeronic gasp of an old man swimming upstream in a river he could never control. He began to have a schizophrenic vision of the cosmos he himself had created, an implosion that produced a fantasy of power in the will to destroy. Which perhaps was a throwback to his original anarchism. If it is correct to say that Mao's most extraordinary accomplishment as a visionary was to ground it in the concrete, to establish prescriptive programmes for highly structured and organized endgames, in the end it was his original successes in doing these things that would prove his undoing. He unleashed a form of idolatry that bordered on radical mysticism. In directing his prophetical claims against the organizations and structures constituting the party and state, he unleashed collective furies tearing down what had been building up. The surviving witnesses were not out of sympathy for this. They were caught up in the youthful enthusiasm of the Red Guards. Indeed, having been disillusioned once before by Stalin and the Soviet Union, they were not willing to be easily disillusioned again. But in the end they were and with both nostalgia and regret.

An unpublished interview with Rewi Alley, whom my wife and I interviewed in 1986 at his home in the residence of the Italian ambassador under Mussolini not long before he died (a place of faded wallpaper, lost grandeur and old memories) may serve as an epitaph to both Maoism and socialism. In his youth a vigorous outward-bound kind of person, now he was confined to a wheelchair and hooked up to various medications. But his mind was clear enough. Alley deplored the preoccupation with money, the market and the inequalities of growth. China's burgeoning growth rate, the introduction of a stock market and the evolution of the banking system were for him pretty excruciating events. For him Indusco, the old system of cooperatives, was still a valid basis for the reconstruction of society. He believed the revolution had accomplished much but he was not at all happy with the general loosening of controls. Indeed in one of his last letters to Mao, he decried the spread of sexually explicit literature to which he attributed the growth of drug taking among the young. 
Above all Rewi Alley deplored the Cultural Revolution. ${ }^{30}$ It represented the destruction of an ideal - certainly his ideal-indeed his abiding faith for most of his entire life in Maoism and the Chinese revolution. He came to believe that Mao himself had betrayed both, as he expressed in the interview:

Rewi Alley: I don't think the [Cultural] Revolution was very kind to Mao. It put him on a pedestal and gave him absolute power. He had a number of very grave weaknesses. One was that he allowed himself to be surrounded by very poor elements - Jiang Qing. I think that was very sad. As he got older, of course, old age took over. He became an old man with Parkinson's very highly developed. He had Parkinson's very badly. He could no longer present the front he would have liked to present. What I found so sad was that he turned on all the people who helped him make the revolution, the very cream of them, and he would have turned on Zhou Enlai but died before he could. Apter: Did he really understand what he was doing?

Rewi Alley: He had that evil genius Kang Sheng at his side all the time putting thoughts into his ear. ${ }^{31}$

It was a melancholy interview ending with that final evasion. Mao had desecrated the Yan'an ideal all right but Alley could still not bring himself to blame Mao directly - rather put it down to Parkinson's disease, or the wicked figure of Kang Sheng. Interviews with Israel Epstein, Sol Adler and others told much the same story, although they varied to some extent about the effects of the turn to market capitalism in China today. All saw in China's remarkable economic success at best a very mixed blessing, and in revolutionary terms something of an admission of failure. How wrong they were if one considers how China has emerged as the most strikingly successful example of developmental change in a world where developmental failure is by far the more common condition.

Which brings me back to political religion and the witnesses. To emphasize the proto-religious aspect of Maoism is not, of course, to obscure its military, political and social aspects. Quite the contrary, these were the proving grounds of its validity. Nor does it add to our understanding just to recount what an evil-doer was the real Mao. More important is to account for the fervour and militancy of the Chinese communists and the discipline that they were able to maintain under extremely harsh circumstances and in terms far more explanatory than a description of Mao as tyrant or, for that matter, theories of rational choice and ordinary political economy. Rather, exploring Maoism in this fashion suggests certain crucial differences between religion and protoreligion, which is also the difference between religion properly speak- 
ing and political religion. What the Mao case suggests is that religions are capable of self-replenishment in a way that political religious are not. Political religious beliefs lose their force over time. Efforts to prop them up become ritualized. The more they become empty and devoid of content, the greater the need to impose orthodoxy as the rationale for authority. In terms of China, one can argue that trying to reverse such a decline was an important factor in the Cultural Revolution for the latter was, in addition to being a power struggle, an effort to bolster a rapidly disappearing faith in socialism altogether. In this, it prefigured a more general decline of socialism everywhere.

In these terms if we look past the arguments, events and ideological claims the witnesses made, and considering how they selected the facts they 'saw' with their own eyes (and all were excellent observers), there remains a constancy of commitment which, if not in itself religious, speaks to a deeper emotional and symbolic attachment to something politically larger than themselves. This attachment, despite its alien origins, came to fit with their own American natural inheritance. In part Maoism served as a substitute for the religions they had been brought up with and the faiths they had lost. It also speaks to their desire for social action. If one reads their writings carefully, one sees how important to them was the revolution itself as a venue for action and engagement. Perhaps to some extent it was also a way of exorcising the fear of loneliness in the absence of belief, and of being so often out of step with prevailing opinion. Such personal factors also help us understand why it is that belief in politics keeps coming back in religious forms.

The Chinese revolution, if nothing else, shows how deep rooted is the desire to believe and how important an ingredient in political action. It also suggests that if political religion fails, as socialism has failed, it leaves a space which real religion can fill, not least of all by its more virulent forms, most particularly of a fundamentalist and evangelical kind. It is not a comforting thought.

David E. Apter is Henry J. Heinz Professor Emeritus of Comparative Political and Social Development; Senior Research Scholar, Yale University.

\section{NOTES}

* An earlier version of this paper was presented at a conference on Mao at the Fairbanks Center, Harvard University in December 2003.

1 Presentism as used here represents the imposition of criteria of the here and now on the then and there. 
2 Mostly it is historians who serve this purpose. One thinks for example of Tocqueville, who was one of the defining figures in the interpretation of the American political experience. How he is reinterpreted is a way of redefining how the American experience is itself understood. Much the same could be said of Michelet on the French revolution. Although he lived after the events, he was writing in their immediate aftermath. His monumental work on the subject served as a point of departure for subsequent revision of that revolution and also the character of historiography on the subject.

3 In effect their views of Mao, Maoism and the Chinese communists, especially in the period roughly from 1936 to 1942, were essentially salvational with Yan'an both a redoubt and a microcosm for China as a whole, and remained so in their minds long after it became apparent that Yan'an could never be a model for anything other than itself. See Saich (1996).

4 All the more so because in China history seemed to repeat itself. Previous American intervention in Russia and the refusal to recognize the Soviet state they considered totally counterproductive. Now in China the United States was pouring funds and armaments into the coffers of GMD in a desperate effort to forestall communism. The results were to worsen already deteriorating conditions, and with little to show for it other than corruption, warlordism and the intensification of the already severe social suffering of ordinary Chinese. More to the point, much of the weaponry wound up in communist arsenals. Moreover these witnesses saw in the West a punitive capitalism, democracies caught in the vice of political opportunism and paralysis, and around them rising militarism in Japan, not to speak of the spread of fascism and Nazism. For all three there remained the residual resonance of the America as New Jerusalem with its Puritan past and high moral resolve. They thought they could see in the Chinese communists a similar kind of commitment. To the extent that they committed brutal acts, these were regarded as ripostes to atrocities and at worst unfortunate concomitants in the course of transforming a reactionary and feudal society. They fervently hoped that the end product would accord with universal principles: greater equality, education and freedom. For such ends they were willing to countenance the need for a tutelary party with its eye on the future and its feet on the ground, turning their eyes from its increasingly authoritarianism, its bureaucratic ruthlessness, and the purging propensities driven by party factionalism. It was only as China became more and more visibly oppressive that they began to look askance; as happened for example, with Eugene Lyons and Freda Utley among many others.

5 They were also competitive, vying for favour within China and the United States. Their efforts to 'de-demonize' Mao meant influencing relations between the United States and China. In this they believed they were motivated by genuine concern for the United States and where its policies were leading. Purporting to offer balanced views of a polarized situation, they gained considerable political influence. Strong carried on a regular correspondence with Eleanor Roosevelt. (Smedley tried to do the same but was given the cold shoulder.) And Snow was extremely influential both in mobilizing public support for China and in his contacts with China hands in the State Department and related institutions. Snow was less interested in Marxism than was Strong (although she was never a great Marxist) and much less of an anarchist than Smedley. In his preferred 'man from Missouri' role, he gave the impression of looking circumstances straight in the face, to tell it like it was to all and sundry whether they liked it or not. Perhaps better than the others, Snow was keenly aware of the limits of what could be said. But all three were good at sensing the way the wind was blowing and all knew the requirements of self-censorship. 
6 Later to be excoriated as apologists and fellow travellers. Efforts to posthumously annul Duranty's Pulitzer Prize were only recently rejected.

7 So much did Helen Snow relive the days of Yan'an that her eighteenth-century house became like a cave, with shrubs covering the walls and hanging from the ceiling.

8 She was particularly good at tidbits. For example, she told me that it was at her insistence (she threatened to leave him) that the biographical materials in Red Star over China remained in the book, Edgar Snow intending to delete it because he believed it too politically sensitive.

9 It was also possible to interview some of those who had originally supported but then turned against the Chinese communists, most particularly Michael Lindsey.

10 In accord with full disclosure I should say that, like a number of foreign observers, I am a member of the Three S Society.

11 For a detailed discussion of Mao's thought see Schram (1989).

12 Rewi Alley, perhaps the most devoted of all the China hands, wrote a short book on those he considered the most significant, particularly Anna Louise Strong, Agnes Smedley and Edgar Snow. There were of course many others. See Alley (1985).

13 Rewi Alley was himself a New Zealander, a member of the New Zealand Communist Party, who went to China to do social work when still young, and wound up establishing industrial cooperatives. Israel Epstein was a refugee who made his way across Siberia to Japan, and then to Shanghai, to serve as a United Press correspondent and despite rough handling during the Cultural Revolution remained an apologist. Michael Snow, speaking of the visits they made to China in the early 1970s said, 'They lied to us.' She indicated that so outraged was she by this, that she had considered disinterring the remains of Edgar who had been buried in China and returning them to the United States.

14 Smedley, for example, 'regarded the Red Army as revolutionary organization of the poor' (1970: 142).

15 Their personal histories reinforced this position. All traced their families back to colonial times. Those born in heartlands like Nebraska and Missouri, and who had come of age in Colorado, California and Washington among other places, were nomads in search of something, not least of all themselves. This marked them off as independent minded, whatever their political preferences. Smedley remained a romantic revolutionary throughout and her clientele was at times more Indian and Asian than American. For her the Chinese revolution was attractive less because it was communist than that it was revolutionary. It was revolution that she believed in. Indeed, so revolutionary was she, particularly with respect to such bourgeois institutions as marriage, or what she regarded as the intrinsically degrading character of male-female sexual relations, that eventually she offended the Puritanism of the Chinese communists who expelled her from Yan'an.

16 Anna Louise Strong, with her Congregationalist background, settlement house propensities, and belief that the communists were the new Puritans, was shocked when she found herself an object of suspicion in the Soviet Union. Indeed, deserted by her old friend Borodin, she was expelled from the Soviet Union and her Russian husband disappeared. For her China was thus a place of refuge.

17 Cited in Strong and Keyssar (1983: 346).

18 As to their own beliefs, all were 'lapsed' from conventional religions - Smedley and Snow from Catholicism, Strong from Congregationalism. Stalinism certainly put them all off, at least at some point. So too did the Cultural Revolution. But religious beliefs are never only about religion. 
19 Such as Maria-Antonietta Macciocci (to her later embarrassment) not to speak of the variety of Mao cultists among European and American intellectuals, writers, artists, etc. See Macciocchi (1971).

20 As he was dying Snow received a letter from Richard Nixon that said he wanted Snow to know that his 'distinguished career is so widely respected and appreciated'.

21 Struggles within were not simply power struggles, although of course they were that, but they were also a competition over which 'truths' would prevail. The battles over the correct lines, left and right, were analogous to schisms and divisions within the church. Indeed, one common link between Soviet purges and conflicts within the CPP were the campaigns to root out Trotskyism, a process that in China was incorporated in the early Rectification Campaigns. For the details of such early struggles within the Chinese Communist Party, see Saich (1996).

In these regards there are parallels between Lenin's redemptive communism and those of Russian writers and intellectuals such as Dostojevsky, who believed that it was in Russia that the Kingdom of God on Earth would arrive, and transform all mankind. As for Mao, Schram notes that what set him apart was his 'overwhelming confidence in his own capacity for leadership. Not only did he admire strong rulers East and West, from the founders of the Ch'in and Han dynasties to Peter the Great and Napoleon, but he was plainly convinced, from early manhood, of his ability to emulate them. Such supreme self-confidence does not in itself guarantee that the possessor will play a significant political role, but it is very difficult to be an effective political leader without it.' See Schram (1989: 7).

23 With rectification went justification. One applauded the specially created revolutionary instruments that pretended to follow institutionally recognized public procedures and gave a veneer of legality to arbitrary decisions about guilt, dissent and betrayal. Moreover, although supposedly internalized by poring over appropriate texts containing Mao's illuminating insights, even the orthodox could be subject to doubts. Political sin and guilt, unlike ordinary crimes, were a matter of social defilement requiring purification by exorcizing and eliminating transgressors. No matter one's rank or position, one's conviction and ethical purity were always subject to suspicion. Individuals, as individuals, had to be tested repeatedly in public rituals, public confession leading to self-abasement. Since rectification required the elimination of doubt, the object was to locate the guilty core in each individual no matter how devoutly doctrinal he or she claimed to be. For that a standard of judgment was required, one that invoked synoptic sayings, made certain texts sacred, consecrated special cadres, all accompanied by public spectacle that was at times sheer theatre. As a process Mao became a figure larger than life with justice as an expression of public 'wrath'. Expressed through the party in the name of the people rather than the glory of god - and repeated on a more massive scale during the Cultural Revolution, Maoism used on both occasions the same lord high executioner, Kang Sheng.

24 For example, as if to distance himself a little from the Chinese communists as well as to disarm his American readers, he referred to the Chinese communists as 'Reds', a term conventionally less than endearing.

25 And so it seemed to be, as long as one did not support the wrong line. To do so revealed the other face of Yan'an, and not nearly as kindly as Snow and the other witnesses made out. Indeed, Snow's later accounts gloss over the fact that those in the party who chose to see Mao's prescriptions as moral pretence more than Marxist enlightenment, and refused to toe the Maoist line, were ruthlessly eliminated, among them Wang Ming, Zhang Goato, Liu Zhidan and Wang Shiwei. See Apter and Saich (1994). 
26 In this sense the difference between Yan'an and the Cultural Revolution was profound and the changing role of Mao was only part of it. In Yan'an not even Mao's most ardent admirers would have considered him in godlike terms, or even in some mystical sense larger than life. In the Cultural Revolution his image became both omnipresent and more remote. His actual portrayal became more and more stylized, ageless, frozen, virtually emotionless and, replicated in countless statues and portraits, Buddha-like. The more public adulation attached to his person, the more remote he became, a figure of abstract personalism.

And one very different from the portrait of Mao written during the early Yan'an days by Edgar Snow. Indeed, the latter ignored the process even though it was going on while he was in Yan'an itself. See Snow (1971: 35).

28 Schram calls it a breviary (1989: 174).

29 He too had been savaged along with virtually all the other significant figures of his generation (and losing his lifetime collection of Chinese antiquities).

30 Interview, July 1986.

\section{REFERENCES}

Alley, Rewi, 1985. Six Americans in China. Beijing: International Culture Publishing Corporation.

Anderson, Benedict 1991. Imagined Communities. London: Verso.

Apter, David E. 1963. 'Political Religion in the New Nations'. In Clifford Geertz (ed.), Old Societies and New States. New York: The Free Press of Glencoe.

Apter, David E. and Saich, Tony 1994. Revolutionary Discourse in Mao's Republic. Cambridge: Harvard University Press.

Callois, Roger 1959. Man and the Sacred. Glencoe: The Free Press.

Chang, Jung and Halliday, Jon 2005. Mao, The Unknown Story. New York: Alfred A. Knopf.

Cohn, Norman 1961. The Pursuit of the Millennium. New York: Harpers.

Fitzpatrick, Sheila 1999. Everyday Stalinism. New York: Oxford University Press.

Frye, Northrop 1976. The Secular Scripture. Cambridge, MA: Harvard University Press.

Hamilton, John Maxwell 1988. Edgar Snow. Bloomington: Indiana University Press.

Koestler, Arthur 1945. The Yogi and the Commissar. New York: Macmillan.

MacFarquhar, Roderick 1974. The Origins of the Cultural Revolution. New York: Columbia University Press (3 volumes).

MacKinnon, Stephen R. 1988. The Life and Times of an American Radical. Berkeley: University of California Press.

Macciocchi, Maria-Antonietta 1971. De la Chine. Paris: Editions du Seuil.

Renan, Ernest 1927, The Life of Jesus, New York: Modern Library.

Ricoeur, Paul 1986. Lectures on Ideology and Utopia. New York: Columbia University Press.

Rue, John E. 1966. Mao Tse-tung in Opposition 1927-1935. Stanford: Stanford University Press.

Saich, Tony 1996. The Rise to Power of the Chinese Communist Party. Armonk, NY: M. E. Sharpe.

Schram, Stuart R. 1969, The Political Thought of Mao Tse-tung. New York: Praegers .

- 1989. The Thought of Mao Tse-tung. Cambridge: Cambridge University Press.

Smedley, Agnes 1970. China Correspondent. London: Pandora Press.

Snow, Edgar, 1970. Red China Today. New York: Random House. 
- 1971. Red China Today. New York: Random House.

- 1972. The Long Revolution. New York: Random House.

- 1984. Red Star over China. 4th printing. New York: Bantam Books [1st edn 1937].

Strong, Anna Louise (1885- ) Letters from China. Peking: New World Press.

Strong, Tracy and Keysser, Helene 1983. Right in Her Soul. New York: Random House.

Tsou Tang 1986. The Cultural Revolution and Post-Mao Reforms. Chicago: University of Chicago Press.

Wakeman, Frederic 1984. The Great Transformation. Berkeley: University of California Press (2 volumes). 